\title{
Small Business Economics Journal Editor of the year award
}

\author{
Zoltan J. Acs for the Editors of Small Business Economics Journal
}

Accepted: 19 August 2018 / Published online: 5 September 2018

(C) Springer Science+Business Media, LLC, part of Springer Nature 2018

Small Business Economics: An Entrepreneurship Journal, founded in 1989, established the editor of the year award in 2017 to recognize significant achievements that have enhanced the quality of scholarship through the editorial process. The award is open to any editor of Small Business Economics.

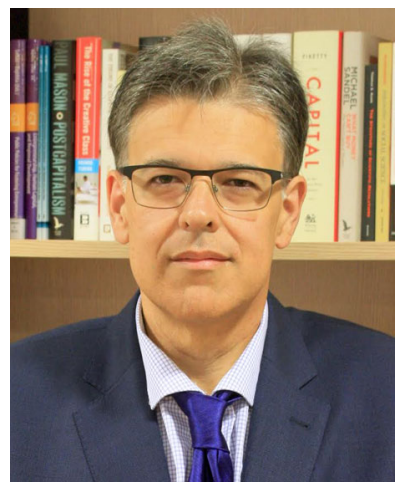

Professor Rui Baptista of the University of Lisbon is the winner of the 2018 Small Business Economics Journal editor of the year award.
Rui Baptista is Department Chair, Engineering Management, and Full Professor in Entrepreneurship and Innovation at Instituto Superior Técnico, University of Lisbon. He teaches in the economics of entrepreneurship and innovation. Rui Baptista is also an international adjunct faculty member with SDS, Carnegie Mellon University. He received his Ph.D., Business Administration: London Business School, University of London. Rui's research and teaching focus mainly on the subjects of entrepreneurship, technological innovation, industry and labor dynamics, and their relationship with economic growth and regional development.

- Since 2016: Editor of Small Business Economics (publisher: Springer).

- Since 2005: Associate Editor of Small Business Economics (publisher: Springer). 